\title{
The HOX-11 Gene is Expressed in Leukemia Cells From Myeloid Lineage
}

\author{
Sofia Mubarika Haryana
}

\begin{abstract}
Abstrak
Telah dilaporkan bahwa over ekspresi gen HOX-11 pada sel Takibat translokasi kromosom menyebabkan leukemia. Pengecekan ekspresi juga dilakukan di sini pada total RNA berasal dari sel leukemia tipe mieloid, menggunakan metode RT-PCR. RNA HOX-11 dideteksi pada 2 dari 9 penderita AML. Hasil ini tidak dapat menyingkirkan kemungkinan bahwa HOX-11 juga menyebabkan leukemia tipe mieloid.
\end{abstract}

\begin{abstract}
It has been reported that overexpression of the HOX-11 gene in $T$ cells by choromosomal translocation causes leukemia. The expression was examined in total RNA from leukemia cells of myeloid lineage by the RT-PCR method. HOX-11 RNA was detected in two out of nine AML patients. These results suggest that HOX-11 also causes leukemia in myeloid lineage.
\end{abstract}

Key words : Leukemia - HOX-11-RT-PCR

\section{INTRODUCTION}

HOX-11 (homeobox 11) was isolated from $\mathrm{T}$ cell in acute Lymphoblastic leukemia (T-ALL) with specific interchromosomal translocation $\mathrm{t}(10 ; 14)$. Ap: proximately $7 \%$ of T-ALL posses the $t(10 ; 14)$ (q24;q11). The $14 \mathrm{q} 11$ represent the alpha and beta subunit of TCR ( $T$ cell receptor). This translocation causes overexpression of HOX-11 in T cells and makes the cells leukemic. It is not known whether HOX-11 participate in other type of leukemia.

In T-ALL the expression of HOX-11 is showed by Northern blotting. However, HOX-11 mRNA was not detected in any other leukemia cells without $(10 ; 14)$ translocation, by the same method. RT-PCR (Reverse transcriptase-Polymerase chain reaction) is a method which can amplify cDNA from a small amount of $\mathrm{RNA}^{2}{ }^{2}$ which can not be detected by Northern hybridization. The method is quite sensitive to detect genetic abberation, and has been extensively used in the diagnosis of genetic disorders, ${ }^{3}$ the detection of nucleic acid sequences of pathogenic organism in clinical samples, the genetic identification of forensic samples 5 and the analysis of mutation in activated oncogenes. ${ }^{6}$

In order to elucidate the involvement of HOX-11 in acute leukemia from myeloid lineage, HOX-11 expression was examined in AML without translocation $\mathrm{t}(10 ; 14)(\mathrm{q} 24 ; \mathrm{q} 11)$ using the RT-PCT method. Since c-fos as a cellular proto oncogene is expressed in a very low state in normal haematopoeitic cells, and thought to participate in leukomogenesis, this gene expression was compared to HOX-11 in this work. 


\section{MATERIALS AND METHODS}

Heparinised venous blood $(10-15 \mathrm{ml})$ was obtained from leukemic patients.

\section{Isolation of humán lymphocytes}

Human lymphocytes were separated from heparinised venous blood by density gradient centrifugation. Briefly, the blood was diluted in saline, overlaid on Ficoll Isopaque (GIBCO, USA) and centrifuged at $400 \mathrm{~g}$ for 40 minutes at $4^{\circ} \mathrm{C}$. The mononuclear cells including lymphocytes which situated at the interface were harvested and washed in phosphate buffered saline three times. After washing, total RNA was immediately isolated from the cells.

\section{Digoxigenin (DIG) labelled cDNA probe for human HOX-11 and c-fos}

DIG labelled cDNA probe for human HOX-11 and c-fos was prepared as previously described. ${ }^{7}$ From the plasmid containing human HOX-11 cDNA, a $160 \mathrm{bp}$ HOX-11 fragment was PCR-amplified with specific primers in the presence of DIG-dNTP labeling mixture. A $489 \mathrm{bp}$ fragment isolated from Apal site in exon- 4 of the c-sfos gene was used as c-fos probe.

\section{RNA Isolation and Northern blotting}

Total RNA was isolated from leukemic cells using guanidine thiocyanate. ${ }^{8}$ Total RNA $(10 \mu \mathrm{g})$ was sizefractionated by electrophoresis on $1 \%$ agarose gel containing $0.5 \%$ formaldehyde and ethidium bromide, transfered to Hybond N-Nylon membranes (Amersham) bycapillary action in $10 \mathrm{X}$ standard saline citrate (10XSSC). After baking $120^{\circ} \mathrm{C}$ for 30 minutes, the membrane was prehybridized at $42^{\circ} \mathrm{C}$ overnight in $5 X S S C, 0.5 \%$ SDS, $2 \%$ blocking reagent, $50 \mathrm{mM} \mathrm{Na}$ Phosphat, $0.1 \%$ lauryl sacorsine and yeast RNA (10 $\mu \mathrm{g} / \mathrm{ml}$ ) and $50 \%$ formamide. Then the membrane was hybridized in the same solution containing DIGlabelled cDNA probe (HOX-11 or c-fos). After a 12 hour hybridization, the membrane was washed twice in $2 \mathrm{XSSC}$ and $0.1 \%$ SDS at room temperature for five minutes then twice in $0.1 \mathrm{X}$ SSC containing $0.1 \%$ SDS at $68^{\circ} \mathrm{C}$ for 30 minutes. Probes on the membrane were detected by chemiluminescent detection kit using antiDigoxigenin antibody.7

\section{Southern blotting and hybridization}

The RT-PCR product of leukemia samples was sizefractionated by electrophoresis on $1 \%$ agarose gel.
Afterwards the gel was denatured and neutralised as mentioned elsewhere, 9 and dry blotted overnight. The filter was prehybridised at $42^{\circ} \mathrm{C}$ for 1 hour and hybridised with $\mathrm{HOX}-11$ probe at $42^{\circ} \mathrm{C}$ overnight. Then the filter was washed with $2 \mathrm{XSSC}$ containing $0.1 \%$ SDS for 10 minutes at room temperature, and $0.1 \mathrm{XSSC}$ containing $0.1 \%$ SDS for 30 minutes at $68^{\circ} \mathrm{C}$. The probes were detected by the chemiluminescent method.

\section{Chemiluminescent detection}

Blotted membrane (Hybond N, Amershan) was washed with $0.3 \%$ tween 20 buffer for five minutes and then reacted with anti-digoxigenin alkaline phosphatase (anti-DIG-AP).

Filter was washed twice in $0.3 \%$ tween 20 buffer for 30 minutes and then incubated for 5 minutes at room temperature in lumigen PPD substrate solution (4-methoxy-4-(3-phosphate-phenyl)) spiro $(1,2$ dioxetane-3,2-adamantane $(1: 100))$. The membrane was exposed to a Kodak X-Omat AR film with an intensifying screen at room temperature and the film was developed. ${ }^{7}$

Reserve transcription and polymerase chain Reaction amplification of HOX-11 mRNA

Oligo nucleotide primers were kindly provided by Dr. Hatano. One microgram of total RNA sediment were diluted in $5 \mu \mathrm{l}$ of RNAse-free water containing 0.01 OD units of random hexanucleotide primer (Takara, Kyoto, Japan). Four microliters of Moloney murine leukemia virus reverse transcriptase (MMLV-RT) buffer (GIBCO, BRL, Gaithersburg, Maryland, USA), $0.1 \mu \mathrm{l}$ of human placentae ribonuclease inhibitor (110 $\mathrm{u} / \mu \mathrm{l}$, Takara), $0.1 \mu \mathrm{l}$ of $5 \mathrm{mM} \mathrm{DTT}, 5 \mu \mathrm{l}$ of $5 \mathrm{mM}$ dNTPs and $1 \mu$ of MMLV-RT ( $200 \mathrm{u} / \mu \mathrm{l}$, Takara) were added. Reverse transcription was performed at $42^{\circ} \mathrm{C}$ for 15 minutes, $99^{\circ}$ to inactivate RNAse inhibitor for 5 minutes, and $5^{\circ} \mathrm{C}$ for 5 minute to cool down. The reaction mixture was stored at $-20^{\circ} \mathrm{C}$.

Five microliters of reserve transcription products were amplified by Taq DNA polymerase (Perkin Elmer Cetus, Norwalk, Connecticut, USA) in a $20 \mu 1$ reaction containing $10 \mathrm{mM}$ Tris-HCL (pH 8.3), 1.5 $\mathrm{mM} \mathrm{MgCl} 2$ and $40 \mathrm{pmol}$ of each primer. The primers were chosen from exon 2 and exon 3 to amplify the cDNA which was reverse transcripted from HOX$11 \mathrm{mRNA}$. Genomic DNA can not be a template for those primers since intron is present between exon 2 and exon 3. 


\section{RESULT}

\section{Expression of HOX-11 mRNA in leukemic samples}

In order to examine HOX-11 expression in leukemia cells from AML and ALL, HOX-11 mRNA in total RNA from leukemia cells was analyzed by the Northern blotting method and hybridization to HOX-11 probe. For positive control total RNA from liver cell line transfected with the HOX-11 gene was used. As shown in Fig. la 3.8 kilo basepair (kb) HOX-11 mRNA was detected in the sample from leukemia cells did not express detectable amount of HOX-11 mRNA. We also examined whether leukemia cells express other oncogenes such as c-fos. The c-fos mRNA transcript of $2.2 \mathrm{~kb}$ was expressed in some of the leukemic samples (Fig. 1b).

As an amount control of mRNA in those samples we used the human G3PDH gene which expressed a $1.6 \mathrm{~kb}$ transcription as probe. Fig $1 \mathrm{c}$ demonstrates that all of the leukemic cells examined expressed almost the same amount of G3PDH mRNA.

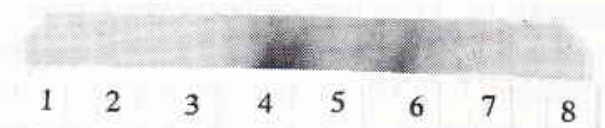

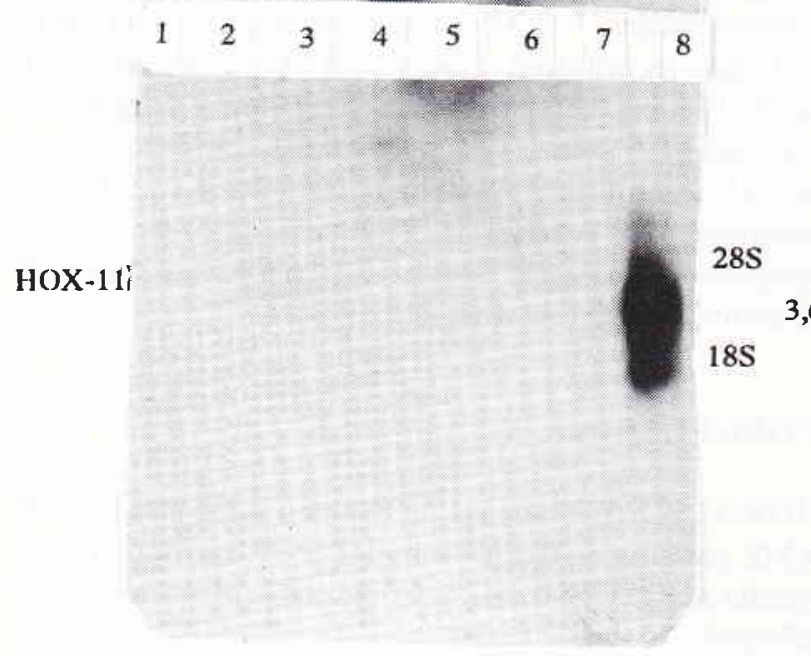

A

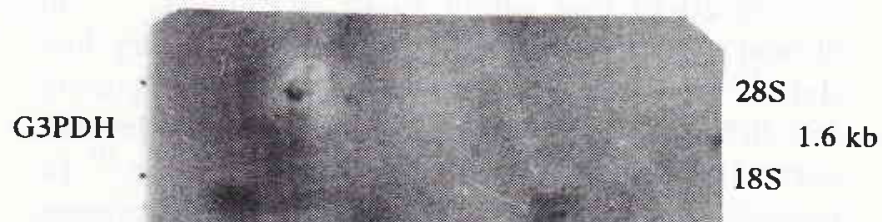

$3,6 \mathrm{~kb}$

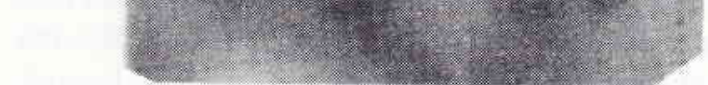

B

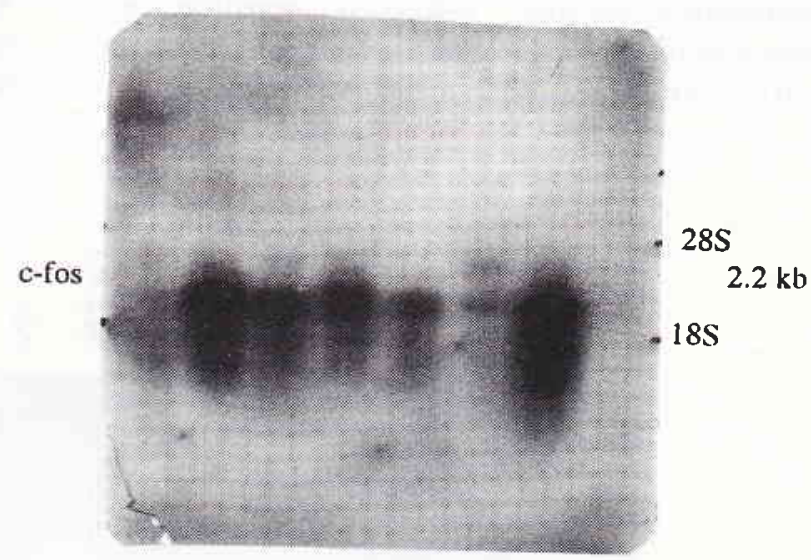

C

Fig. I : Analysis of HOX-II expression in leukemia cells, using the Northern blotting method.

a) $H O X-11$, b) c-fos and c) G3PDH IIRNA expressions were analyzed in total RNA from leukemia cells.

Lane $I: A L L-L I \quad 2: A M L-M 3$

3:AML-MI 4:ALL+Rb

$5: A L L \quad 6: A M L$

7:AML-M5 8: HOX-11 transfected liver cell line.

$A L L-L 1=$ Acute lymphoblastic leukemia $L 1$ type

AML M1 = Acure myeloblastic leukemia MI type

AML M3 = Acute myeloblastic leukemia M3 type

AML M5 = Acute myeloblastic leukemia M5 type

$R b \quad=$ Retinoblastoma 
In order to confirm whether HOX-11 is expressed in the samples, the product of the RT-PCR of the samples was subjected to Southern blotting and hybridized to HOX-11 probe. The results shown in Fig. 2 demonstrate that one (ALL-L1) out of 4 ALL, and 2 (AML-M3 and AML-M5) out of 9 AML patients expressed HOX-11 mRNA.

\section{DISCUSSION}

All of the leukemic samples expressed c-fos mRNA by Northern hybridization. c-fos is a cellular proto oncogene which is induced 5 minutes after treatment with many stimulants, and the level of c-fos mRNA increases $20-30$ fold within 15 to 30 minutes. ${ }^{10,11}$ In normal condition c-fos only expressed in very low state. ${ }^{10,12} \mathrm{c}$-fos is thought to participate in cell growth and differentiation. ${ }^{12} \mathrm{c}$-fos is expressed at low level in normal erythroid cells and erythro-leukemia. ${ }^{10}$ In haematopoeitic cells of myeloid lineage, cells express high level of c-fos. ${ }^{13}$ Fig. $1 \mathrm{~b}$ also demonstrates that two AML samples express c-fos mRNA. The role of $\mathrm{c}$-fos in normal myelopoeisis and in leukemogenesis has not been established. ${ }^{14} \mathrm{c}$-fos expression is increased in myeloid $\mathrm{ml}$ to terminal differentiation if there is genetic lesion affecting $\mathrm{c}$-fos expression, $\mathrm{c}$-fos might play an important role in the development of preleukemic myelodysplastic syndrome ${ }^{14} \mathrm{c}$-fos is not constitutively expressed in lymphocytes. However, large amounts of c-fos RNA were detected in all of the samples from
ALL. ${ }^{15}$ These results suggest that overexpression of c-fos causes leukemogenesis of lymphocytes.

HOX-11 (homeobox 11) mRNA is not detected in all cells by Northern blotting method. It is thought that abnormal expression of homeobox gene is one of the abnormalities associated with the development of murine and human leukemia. ${ }^{13}$ Expression of the HOX-2 gene in transfected clone had been shown to inhibit the pathway of the myeloid differentiation. This abnormal expression of HOX-2 may contribute to the development of leukemia by interfering the differentiation program. ${ }^{13}$

Since HOX-11 is one of homeobox genes, ${ }^{1}$ it is thought that it might play a role in cell growth and differentiation. ${ }^{16}$ HOX-11 is expressed in liver cells and also in children T-ALL. ${ }^{\prime}$ It is not known that HOX-11 play an important role in leukemogenesis. Our results (Figure 2) show that HOX-11 is expressed in ALL (lane 1) and AML samples (lane 4 and 8). As mentioned by Lord et al. This gene is expressed in lymphoid lineages as well as in myeloid lineages and in cell with terminal differentiation. ${ }^{15,16}$

\section{CONCLUSION}

HOX-11 is expressed is one out of 4 ALL and 2 out 9 AML patients, as detected by RT-PCR method, These results suggest that HOX-11 causes leukemo-genesis of myeloid lineage cells.

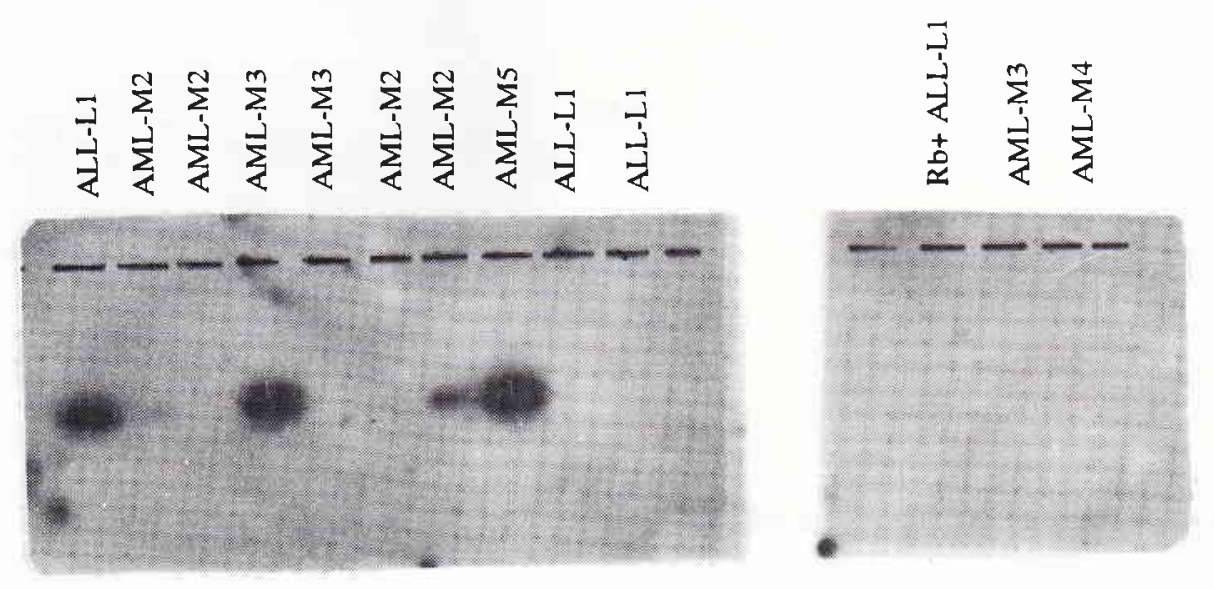

Fig. 2: Analysis of HOX-11 expression in leukemia cells using RT-PCR and Southern blotting method. $H O X-11$ expression was analyzed on Southern blotted RT-PCR products from the leukemia cells.

ALL-LI = Acute lymphoblastic leukemia LI type

AML M2 = Acute myeloblastic leukemia M2 type

AML M3 = Acute myeloblastic M3 type

AML M4 = Acute myeloblastic leukemia M4 type

$R b$

= retinoblastoma 


\section{Acknowledgment}

We wish to thank Prof. T. Tokuhisa for reviewing and correcting the manucsript and Dr. Hatano who provided the probe. This research is sponsored by the JSPS-grant.

\section{REFERENCES}

1. Hatano M, Roberts CWM, Mindew M, Crist WM, Korsmeyer SJ. Deregulation of a homeobox gene HOX-11, by the $t(10 ; 14)$ in T cell leukemia. Science $1991 ; 253: 79-82$.

2. Saiki RK, Gelfand DH, Stoffel S, Scharf SJ, Higuchi R, Harn GT, et al. Primer directed enzymatic amplification of DNA with themostable DNA polymerase. Science 1988; 239 : 487-8.

3. Vigilant L, Pennington H, Harpending H, Kocher TD, Wilson AC. Mitochondrial DNA sequences in single hair from a Southern African population. PNAS USA 1989; 86 : $9350-$ 4.

4. Kwok S, Higuchi R. Avoiding false positive with PCR. Nature $1989 ; 339: 237-8$

5. Higuchi R. Simple and rapid preparation of samples for PCR. In: Ehrlich HA (ed). PCR technology. New York NY: Stockhlom, 1989.

6. Neubauer A, Neubauer B, Lin E. Polymerase chain based assay to detect allelic loss in human DNA : loss of interferase gene in chronic myelogenesis leukemia. Nuc Acid Res $1990 ; 321: 1689-95$.
7. Boehringer Mannheim. Manual Detection of DIG labelled nucleic Acids. 1993.

8. Maniatis. RNA Isolation. In: Laboratory Manual on Molecular Cloning. New York: Cold Spring habor, 1989.

9. Chirgwin JM, Przybyla AE, MacDonald RJ, Rutter WJ. Isolation of biologically active ribonucleic acid from sources enriched in Ribonuclease. Biochemistry 1979; 18 : 5294-9.

10. Lezenes R, Meneceur P, Ray D, Morean-Grachelin F. Proto oncogene expression in normal, preleukemic and leukemic murine erythroid cells and its relationship to differentiation and proliferation. Cancer Res 1988; 48 : 3972-6.

11. Miller AD, Curran T, Verma IM. c-fos protein can induce cellular transfonnation : a novel mechanism of activation of a cellular oncogene. Cell 1984; $36: 51-4$.

12. Januwein T, Muller R. Structure Function analysis of fos protein : A single amino acid change activates the immortalizing potential of $v$-fos. Cell 1987; $48: 647-48$.

13. Blatt C, Intam J, Sachs I. Inhibition of spesific pathways of myeloid cell differentiation by an activated HOX 2-4 homeobox gene. Cell Growth Differ 1992; Oct. 3 : 671-76.

14. Lord KA, Abdollahi A, Liebermann B, Hoffam I, Liebennan DA. Proto oncogenes of the fos/jun family of transcription factors are positive regulators of myeloid differentiation. Mol Cell Biol 1993; 13 : 841-51.

15. Haryana SM. Over expression of c-myc c-myb c-fos in several cases of ALL AML from Jogjakarta province, ICMR 1992, Unpublislied data.

16. Watson JD, Gilman M, Witkowski J, Zoller M. (eds) Genes that control the development of Drosophila. In: Recombinant DNA. New York: WH Freeman and Co, 1992. 